\title{
Evaluation of Groundwater Quality Using Groundwater Quality Index (GWQI) in Sharjah, UAE
}

\author{
Naseraldin Kayemah ${ }^{1, *}$, Rami Al-Ruzouq ${ }^{1}$, Abdallah Shanableh ${ }^{2}$, and Abdullah Gokhan Yilmaz ${ }^{3}$ \\ ${ }^{1}$ University of Sharjah, Department of Civil and Environmental Engineering, 27272 Sharjah, United Arab Emirates \\ ${ }^{2}$ University of Sharjah, Research Institute of Sciences and Engineering, 27272 Sharjah, United Arab Emirates \\ ${ }^{3}$ La Trobe University, School of Engineering and Mathematical Sciences, Department of Engineering, Melbourne, 3086 Victoria, \\ Australia
}

\begin{abstract}
The rapid growth in the world population resulted in an increase of the freshwater needs in many sectors. Groundwater is the most important freshwater source specially for arid and semi-arid regions due to lack of surface water sources and low precipitation rates in those regions. In this study, monthly groundwater quality data were collected from eleven well fields in Sharjah over the period of 2004-2017. Water quality parameters including bicarbonate, calcium, chloride, fluoride, magnesium, sodium and sulphate were selected for the analysis. In the study, water quality index (WQI) process is used to develop groundwater quality index (GWQI) for Sharjah using above mentioned water quality parameters. Mann-Kendall and Spearman's Rho tests were adopted as non-parametric trend tests for temporal (trend) analysis of GWQI, whereas inverse distance weighting interpolation was used in GWQI spatial trend analysis. Temporal trend analysis results showed significant trends in 8 out of 11 well fields. Spatial analysis showed the highest values for salinity ions in the well fields closest to the northern region, whereas the lowest values were detected in the southern region.
\end{abstract}

\section{Introduction}

The rapid growth in the world population resulted in an increase of the freshwater needs in many sectors [1]. Groundwater is the most important freshwater source specially for arid and semi-arid regions due to lack of surface water sources and low precipitation rates in those regions. Around $25 \%$ to $40 \%$ of the drinking water in the world is extracted from groundwater [2].

Groundwater is a renewable source that can be recharged naturally by precipitation [3]. It is more desired choice for many purposes compared to surface water due to the existence of dissolved minerals in groundwater combined with some of its special characteristics [4]. Groundwater is in general in good quality and less prone to seasonal variations [5].

Groundwater can be affected by many factors such as the increase of the irrigation activities, industrialization and urbanization [6]. Due to increase of industrial freshwater needs along with the use of synthetic fertilizers, pesticides and insecticides for agriculture production can cause serious concerns regarding the groundwater contaminations [7]. In addition, lack of management of the groundwater use that can lead issues such as sea water intrusion [8], human health and plant growth problems [9]. It also effects the economic development and social prosperity [2]. In many cases, groundwater contamination is irreversible and stopping the source of pollutants will not restore its quality [10]. In many countries, bad drinking water quality can lead to serious and dangerous illness that would be major cause of death [1].
Considering above-explained importance of the groundwater, it is important to have an effective and sustainable groundwater management to keep groundwater sufficient (in terms of quality and quantity) for the present use and the future [11]. Groundwater monitoring is an essential component of effective groundwater management. In groundwater monitoring, water quality index (WQI) is widely used. The WQI is outcome of a rating process to provide an overall representation of the groundwater quality using water quality parameters. This technique is used to decrease the large amount of water quality parameters in a single numerical value to assess groundwater quality status [12].

The WQI is a method to explain the water quality in a single dimensionless number and it can be established by aggregating the measurements of a selected water quality parameters [13]. The WQI studies started in 1965 [14]. After that, many researchers and organizations started to develop and modify WQIs (e.g., [15-18]). WQI has become significant and widely used method for water quality monitoring to assess the water quality for different purposes due to its simplicity. WQI transforms all the selected water quality parameters into a single numerical number that can represent the overall quality of different water bodies while taking into consideration the contribution of each parameter. A WQI can be adopted to compare the water quality of different locations and water bodies without referring to statistical assessment for water quality data $[17,19]$. It is very useful tool for decision making for the water authorities [20-22]. Due to its several advantages, the WQI has been adopted by many

* Corresponding author: u18200520@ sharjah.ac.ae 
organizations and agencies throughout the world (e.g., [5, $15,17,18,23,24])$

Several studies developed WQIs for different purposes over different geographical locations. However, there is no study in the literature for a WQI to assess groundwater quality in UAE. Therefore, this research aims to develop a groundwater quality index (GWQI) for Sharjah, UAE to assess the groundwater quality for domestic use. In this study, The GWQI is developed and applied spatially around the study area, and critical points in terms of groundwater quality are identified.

\section{Study Area}

The study area, Emirate of Sharjah, UAE is located along the northern coast of the Persian Gulf on the Arabian Peninsula with a central coordinate of $25.3^{\circ} \mathrm{N} 55.5^{\circ} \mathrm{E}$, approximately $166 \mathrm{~km}$ Northeast of the city of Abu Dhabi. Sharjah covers an area of about $2,590 \mathrm{~km}^{2}$. Sharjah is considered as an arid region where the average annual rainfall is about $100 \mathrm{~mm} /$ year. The average daily capacity and production of groundwater is 21.5 and 15.46 million gallons respectively. Most of the extracted groundwater is used for irrigation purposes [25].

There are 11 well fields that have been taken into consideration for this study (Sadia, Tawi Awaid, Badai, Falah, Ghoreefa, Hamdah, Madam, Mohadab, Seih Aqareb, Seih Harmal and Wahoosh) which are displayed in the Figure 1. The well fields are approximately evenly distributed between the coastline and the mountainous region of Sharjah. Monthly groundwater quality data from the well-fields over the period of 2004-2017 were employed in this study.

Based on availability of data and number of samples from the well fields, water quality parameters including bicarbonate $\left(\mathrm{HCO}_{3}{ }^{-}\right)$, calcium $(\mathrm{Ca})$, chloride $(\mathrm{Cl}-)$, fluoride $(\mathrm{F})$, magnesium $(\mathrm{Mg})$, sodium $(\mathrm{Na})$ and sulphate (SO4-) were selected for analysis.

\section{Methodology}

\subsection{Temporal trend analysis}

\subsubsection{Mann-Kendall (MK)}

The MK test is a non-parametric test and used in several trend analysis studies [26-34]. The z-statistics for this test can be calculated by:

$$
\mathrm{z}=\left\{\begin{array}{c}
\frac{S-1}{\operatorname{Var}(S)} \text { if } S>0 \\
0 \quad \text { if } S=0 \\
\frac{S+1}{\operatorname{Var}(S)} \text { if } S<0
\end{array}\right.
$$

The S value can be computed by:

$$
S=\sum_{k=1}^{n-1} \sum_{j=k+1}^{n} \operatorname{sgn}\left(x_{j}-x_{k}\right)
$$

where $x j-x k$ are the sequential data values, and $n$ is the number of data. sgn can be found by:

$$
\operatorname{sgn}\left(x_{j}-x_{k}\right)= \begin{cases}1 & \text { if } x_{j}-x_{k}>0 \\ 0 & \text { if } x_{j}-x_{k}=0 \\ -1 & \text { if } x_{j}-x_{k}<0\end{cases}
$$

The $\operatorname{Var}(\mathrm{S})$ can be calculated using:

$$
\operatorname{Var}(S)=\frac{n(n-1)(2 n+5)}{18}
$$

In this test, the positive test statistic shows that there is an increasing trend, whereas the negative test statistic shows that there is decreasing trend. The null hypothesis (H0) of the MK test is "There is no trend". If the calculated $\mathrm{z}$ statistics is larger than critical values that are derived from normal distribution tables at specific significance levels (i.e., 0.1, 0.05, 0.01 significance levels), then $\mathrm{H} 0$ is rejected, and the alternative hypothesis HA, which is "there is a trend", is accepted [31].
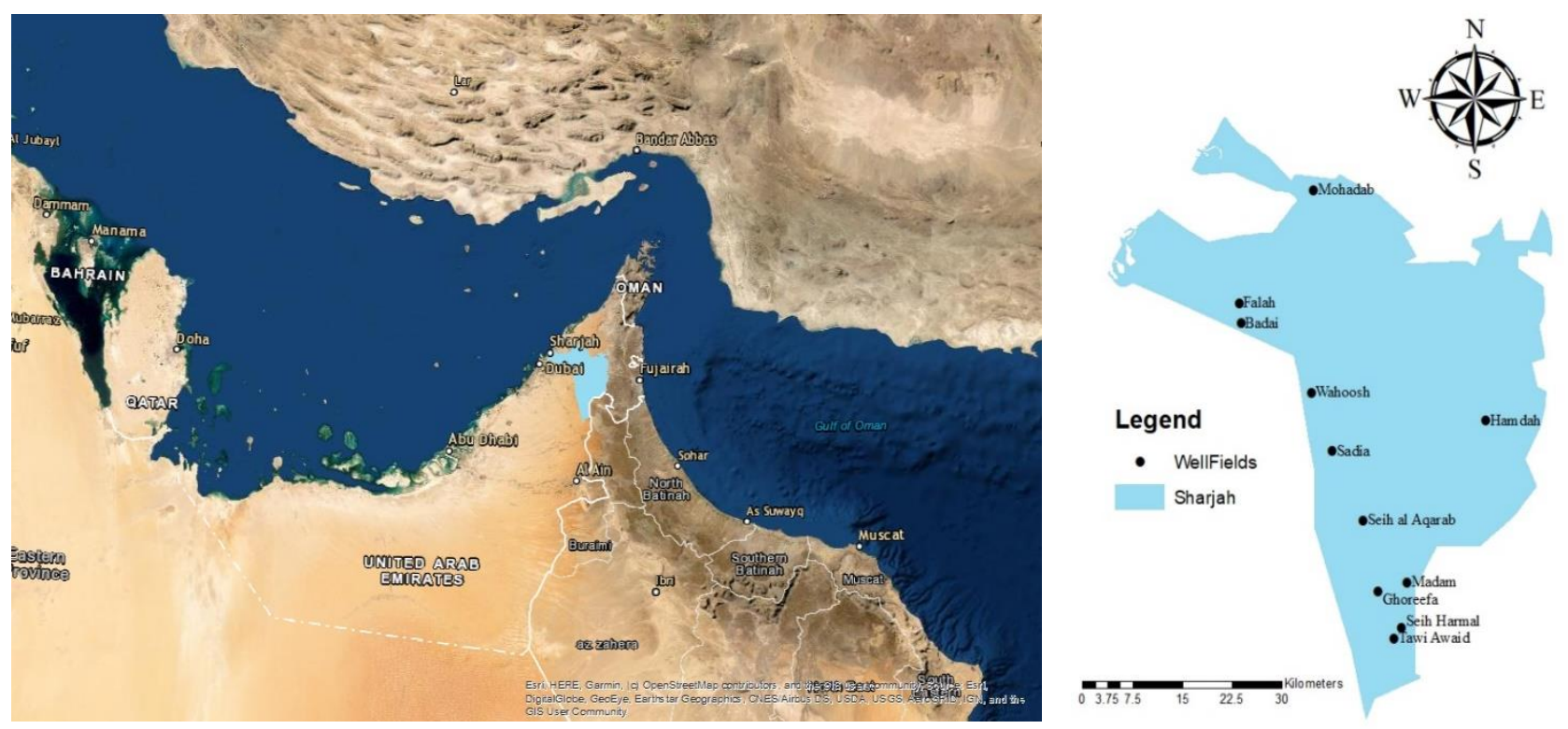

Fig. 1. Study area and location of the wellfields. 


\subsubsection{Spearman's Rho (SR)}

The SR test is a rank-based test that is used to find the correlation between two variables is significant. One variable is considered as the time itself in the SR test, while the other variable is the equivalent time series data. The time series values are replaced with their ranks, and the SR test statistic $\rho_{\mathrm{s}} \mathrm{s}$ is calculated as shown:

$$
\rho s=\frac{S x y}{(S x S y)^{0.5}}
$$

Where:

$$
\begin{gathered}
\mathrm{Sx}=\sum_{i=1}^{n}(X i-X)^{2} \\
\mathrm{Sy}=\sum_{i=1}^{n}(Y i-Y)^{2} \\
\mathrm{Sxy}=\sum_{i=1}^{n}(X i-X)(Y i-Y)
\end{gathered}
$$

The $\mathrm{z}$ statistic can be computed by:

$$
\mathrm{Z}=\rho_{\mathrm{s}}(n-1)^{0.5}
$$

In these equations, $\mathrm{Xi}$ corresponds to the time, $\mathrm{Yi}$ is the variable of interest, $\mathrm{X}$ and $\mathrm{Y}$ refer to the average values of $\mathrm{Xi}$ and Yi. Null and alternative hypothesis of the SR test are the same as the MK test, furthermore the procedure of the SR test to determine whether there is a trend is same as that of the MK test [31].

\subsection{Spatial analysis}

Spatial analysis is the analysis of data over an area. The Inverse Distance Weighting interpolation (IDW) method is used for spatial analysis [32]. The IDW is simple and easy to use. It basically assumes the unknown value in a certain point by approximating a weighted average of values at point within a certain limit of distance. The math behind IDW is that the weights are inversely proportional to a power of distance. Eq. 10 represents the calculation for IDW.

$$
X_{p}=\frac{\sum_{i=1}^{n}\left(\frac{X_{i}}{d_{i}^{p}}\right)}{\sum_{i=1}^{n}\left(\frac{1}{d_{i}^{p}}\right)}
$$

Where $X_{p}$ is the unknown value point, $X_{i}$ the value of a close point, $d_{i}$ is the distance between the unknown and known point and $\mathrm{p}$ is a parameter that represents the power.

\subsection{Groundwater quality index}

Water quality index (WQI) process is used to develop groundwater quality index (GWQI) for Sharjah. GWQI is outcome of a rating process to provide an overall representation of the groundwater quality using water quality parameters. This technique is used to decrease the large amount of water quality parameters in a single numerical value to assess groundwater quality status. This method has been used in many groundwater analysis studies [35-40] In general, there are 3 main steps required to develop the WQI. These steps are assigning weights, calculating rating scale and aggregation of sub-indices to produce the final index. Details of the steps are explained in the following sections.

\subsubsection{Establishing weights}

In this step, weights for each parameter will be assigned depending on their importance and significance on the final index. Weights in general can be equal and unequal. Equal weights are assigned to the parameters when the parameters have equal importance. Whereas unequal weights are assigned to parameters when the parameters have more or less importance than others. It is worth to mention that equal weights are used when the index developers have doubts in the subjectivity of the experts' opinions in reaching convergence. Furthermore, using different weights can show sensitivity in the final index towards heavily weighted parameter. This application is very important in some specific uses such as the aquatic life. In this study, weights are assigned to the selected parameters according to importance on the groundwater quality for domestic use. The relative weight $\mathrm{W}_{\mathrm{i}}$ can be found by the following equation:

$$
W_{i}=\frac{w_{i}}{\sum_{i=1}^{n} w_{i}}
$$

Where $\mathrm{W}_{\mathrm{i}}$ is the relative weight for each parameter, $\mathrm{W}_{\mathrm{i}}$ is the weight assigned for each parameter and $\mathrm{n}$ is the number of parameters selected.

\subsubsection{Rating scale}

The second step in the water quality index is calculating the rating scale. The objective of this step is to transform all the selected parameters into common scale since the parameters in general have different units. Furthermore, the ranges of the parameters can differ from one to another from the same unit. Due to these reasons, this step is very important to proceed in establishing the water quality index. In this study, the rating scale was calculated depending on the permissible limits from a legal standard from the Abu Dhabi Water Quality Regulations (ADWQR). The use water quality standards facilitate subdivision of rating scale values which gives more information to the users (House, 1986). In this method, the critical points which are used to develop the rating scale can be found by using the permissible limits for domestic use. The following equation is used to develop the subindex value in this method:

$$
R_{i}=\left(\frac{x_{i}}{x_{p l}}\right) \times 100
$$

Where $R_{i}$ is the rating scale value, $x_{i}$ is the actual parameter value and $x_{p l}$ is the permissible limit value. 


\subsubsection{Aggregation of sub-index}

After assigning weights and calculating the rating scales of every parameter, aggregation of sub-indices with their weights is the final step to generate the final GWQI. In this study, arithmetic with un-equal weights approach has been used for sub-index aggregation. This method is simple and commonly used among the WQIs developers. The final index value can be calculated by the following equations:

$$
\begin{aligned}
& \mathrm{SI}_{\mathrm{i}}=\mathrm{W}_{\mathrm{i}} \mathrm{R}_{\mathrm{i}} \\
& G W Q I=\sum S I_{i}
\end{aligned}
$$

Where SIi is the sub-index value and $\mathrm{W}_{\mathrm{i}}$ is the relative weight of each parameter and the total weights for all the parameter is equal to 1 . The sub-index interpretation will be divided into different classification which are shown in Table 1.

Table 1. Water quality classifications as determined by the final aggregated index.

\begin{tabular}{|l|l|}
\hline Final aggregated GWQI & Water quality classification \\
\hline$<50$ & Excellent \\
\hline $50-100$ & Good \\
\hline $100-200$ & Poor \\
\hline $200-300$ & Very poor \\
\hline$>300$ & $\begin{array}{l}\text { Water unsuitable for domestic } \\
\text { purpose }\end{array}$ \\
\hline
\end{tabular}

As shown in Table 1, low GWQI values represent good groundwater quality, whereas high GWQI values represent bad groundwater quality.

\section{RESULTS and discussion}

Table 2 shows simple statistics (average, maximum and minimum) for all the selected parameters along with their ADWQR permissible limits and relative weights.

It can be seen from Table 2 that bicarbonate values ranged between 78 and $196 \mathrm{mg} / \mathrm{L}$ with an average of 116 $\mathrm{mg} / \mathrm{L}$, the permissible limit for bicarbonate is $300 \mathrm{mg} / \mathrm{L}$. The weight assigned for bicarbonate was 3 and the relative weight was found to be 0.12 . Calcium values ranged between 14 and $131 \mathrm{mg} / \mathrm{L}$ with an average of $50 \mathrm{mg} / \mathrm{L}$, the

(a)

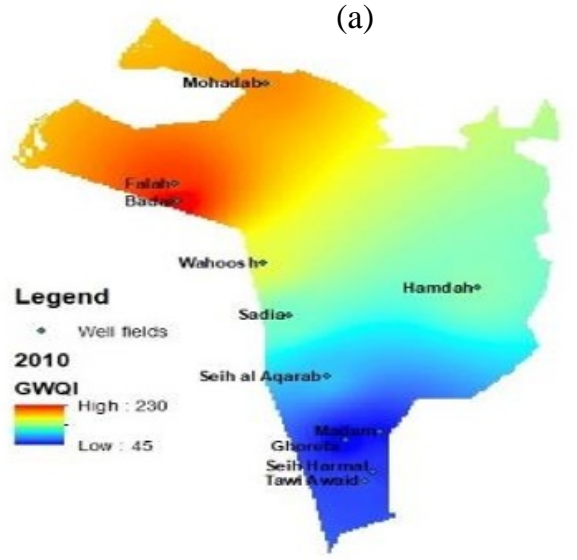

permissible limit for calcium is $80 \mathrm{mg} / \mathrm{L}$. The weight assigned for calcium was 2 and the relative weight was found to be 0.08 . Chloride values ranged between 100 and $1258 \mathrm{mg} / \mathrm{L}$ with an average of $506 \mathrm{mg} / \mathrm{L}$, the permissible limit for chloride is $250 \mathrm{mg} / \mathrm{L}$. The weight assigned for chloride was 5 and the relative weight was found to be 0.19 . Fluoride values ranged between 0.1 and $1.1 \mathrm{mg} / \mathrm{L}$ with an average of $0.5 \mathrm{mg} / \mathrm{L}$, the permissible limit for fluoride is $1.5 \mathrm{mg} / \mathrm{L}$. The weight assigned for fluoride was 5 and the relative weight was found to be 0.19 . Magnesium values ranged between 17 . and $135 \mathrm{mg} / \mathrm{L}$ with an average of 53 $\mathrm{mg} / \mathrm{L}$, the permissible limit for magnesium is $30 \mathrm{mg} / \mathrm{L}$. The weight assigned for magnesium was 2 and the relative weight was found to be 0.08 . Sodium values ranged between 80 and $804 \mathrm{mg} / \mathrm{L}$ with an average of $346 \mathrm{mg} / \mathrm{L}$, the permissible limit for sodium is $150 \mathrm{mg} / \mathrm{L}$. The weight assigned for sodium was 4 and the relative weight was found to be 0.15 . Sulphate values ranged between 58 and $1103 \mathrm{mg} / \mathrm{L}$ with an average of $277 \mathrm{mg} / \mathrm{L}$, the permissible limit for sulphate is $250 \mathrm{mg} / \mathrm{L}$. The weight assigned for sulphate was 5 and the relative weight was found to be 0.19 .

Table 2. Descriptive statistics and permissible limits of water

\begin{tabular}{|c|c|c|c|c|c|c|}
\hline & Avg & Max & Min & $\begin{array}{l}\text { AD } \\
\text { WQ } \\
\mathrm{R} \\
\end{array}$ & $\begin{array}{l}\text { Wei } \\
\text { ght }\end{array}$ & $\begin{array}{l}\text { Relati } \\
\text { ve } \\
\text { weight }\end{array}$ \\
\hline $\begin{array}{l}\text { Bicarbonate } \\
(\mathrm{mg} / \mathrm{L})\end{array}$ & 116.9 & 196.5 & 78.5 & 300 & 3 & 0.12 \\
\hline $\begin{array}{l}\text { Calcium } \\
(\mathrm{mg} / \mathrm{L})\end{array}$ & 50.4 & 131.2 & 14.0 & 80 & 2 & 0.08 \\
\hline $\begin{array}{l}\text { Chloride } \\
\text { (mg/L) }\end{array}$ & 506.3 & 1258.0 & 99.6 & 250 & 5 & 0.19 \\
\hline $\begin{array}{l}\text { Fluoride } \\
(\mathrm{mg} / \mathrm{L})\end{array}$ & 0.5 & 1.1 & 0.1 & 1.5 & 5 & 0.19 \\
\hline $\begin{array}{l}\text { Magnesium } \\
(\mathrm{mg} / \mathrm{L})\end{array}$ & 53.6 & 135.6 & 17.1 & 30 & 2 & 0.08 \\
\hline $\begin{array}{l}\text { Sodium } \\
(\mathrm{mg} / \mathrm{L})\end{array}$ & 346.3 & 804.9 & 80.5 & 150 & 4 & 0.15 \\
\hline $\begin{array}{l}\begin{array}{l}\text { Sulphate } \\
(\mathrm{mg} / \mathrm{L})\end{array} \\
\end{array}$ & 277.0 & 1103.3 & 58.3 & 250 & 5 & 0.19 \\
\hline & & & & & 26 & 1 \\
\hline
\end{tabular}
quality parameters.

(b)

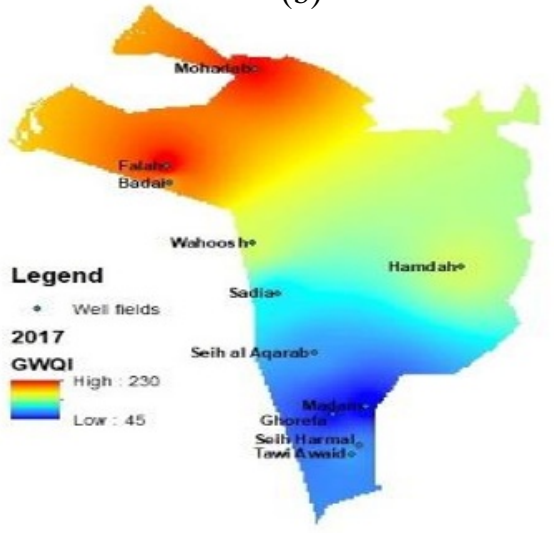

Fig. 2. GWQI Map (a) in 2010 (b) in 2017 


\subsection{Temporal trend analysis}

Table 3 showed GWQI trend analysis results for MK and SR tests. Significance level of the trends (if there is a statistically significant trend) are shown in parentheses.

Table 3. MK and SR results

\begin{tabular}{|l|l|l|}
\hline & MK & SR \\
\hline Badai & $\mathbf{- 2 . 3 5 1 ( 0 . 0 5 )}$ & $\mathbf{- 2 . 4 ( 0 . 0 5 )}$ \\
\hline Falah & $\mathbf{- 1 . 6 7 5 ( 0 . 0 5 )}$ & $\mathbf{- 1 . 9 7 1 ( 0 . 0 5 )}$ \\
\hline Ghoreefa & $\mathbf{4 . 0 0 3 ( 0 . 0 1 )}$ & $\mathbf{3 . 7 8 2}(\mathbf{0 . 0 1 )}$ \\
\hline Hamdah & 0.356 & 0.051 \\
\hline Madam & -0.616 & -0.518 \\
\hline Mohadab & -0.755 & -0.807 \\
\hline Sadia & $\mathbf{- 2 . 4 5 2}(\mathbf{0 . 0 5})$ & $\mathbf{- 2 . 8 1 9}(\mathbf{0 . 0 1})$ \\
\hline Seih Aqarab & $\mathbf{- 3 . 5 4 5}(\mathbf{0 . 0 1})$ & $\mathbf{- 3 . 4 8}(\mathbf{0 . 0 1})$ \\
\hline Seih Harmal & $\mathbf{1 . 9 7}(\mathbf{0 . 0 5})$ & $\mathbf{1 . 9 4 5}(\mathbf{0 . 1 0})$ \\
\hline Tawi Awaid & $\mathbf{3 . 2 1 1}(\mathbf{0 . 0 1})$ & $\mathbf{3 . 0 0 8}(\mathbf{0 . 0 1})$ \\
\hline Wahoosh & $\mathbf{- 3 . 4 3 3 ( 0 . 0 1 )}$ & $\mathbf{- 3 . 3 0 5}(\mathbf{0 . 0 1})$ \\
\hline
\end{tabular}

As can be seen from Table 3, there are increasing GWQI trends in Ghoreefa, Hamdah, Seih Harmal and Tawi Awaid well fields. Among those, increasing trends in Ghoreefa, Seih Harmal and Tawi Awaid are statistically significant. Decreasing GWQI trends were detected in Badai, Falah, Madam, Mohadab, Sadia, Seih Aqarab and Wahoosh well fields. Among these trends, decreasing trends in Badai, Falah, Seih Aqarab, Wahoosh and Sadia showed statistically significant trends as shown in Table 3.

\subsection{Spatial analysis}

It can be seen from Figure 2 that the GWQI values show large variation over the region. There is a clear pattern change from south to north. Figure 2 indicates that the southern part of the study has the best GWQI results. In the southern region, GWQI went up to 45 corresponding to excellent quality. The GWQI values increase towards the northern part of the study area showing the worst values at the far northern side. In Figure 2, part (a) shows values of GWQI in 2010 and part (b) shows values of GWQI in 2017. There is a slight change in the GWQI over 2010-2017 based on comparison of Figure 2 (a) and (b). The change can be recognized mainly in the southern part of the study area indicating a slight increase in the overall GWQI. Since the selected parameters are all related to salinity, it can be stated that the main problem in northern part of the study area is groundwater salinity.

\section{Conclusion}

In this study, seven water quality parameters taken from eleven wellfields were used to develop a GWQI. Trend analysis of GWQI was conducted using MK and SR tests. Spatial analysis was carried out using inversed distance weighting method and different groundwater quality index maps were generated. The followings are major conclusions of this study:

- $\quad$ Significant increasing GWQI trends were found in Ghoreefa, Seih Harmal and Tawi al Awaid meaning deterioration of groundwater quality.

- $\quad$ Significant decreasing GWQI trends were found in Badai, Falah, Sadia, Seih Aqarab and Wahoosh.

- Generated GWQI map showed that the best groundwater quality (lower GWQI values) was found in the southern side of the study area. On the other hand, the worst groundwater quality (higher GWQI values) was identified in the northern part of the study area.

- Spatial analysis of the GWQI showed that GWQI values has increased over time which means the quality of groundwater is decreasing.

- The groundwater aquifer is mostly facing the issue of salinity.

- It is important to mention that in the southern part of the study area, trend analysis showed an increasing trend in GWQI (which means that the groundwater quality is getting worse) in most of the well fields, but in spatial analysis, the southern part showed the best GWQI values. For the northern part, trend analysis showed decreasing trend in GWQI (which means that the groundwater quality is getting better) in most of the well fields, but in spatial analysis it showed the worst values.

This study is expected to provide useful information for the decision makers of groundwater management authorities. It is shown in this study that groundwater salinity is an important problem in Sharjah requiring a quick and effective action.

\section{Funding}

The project was jointly funded by the University of Sharjah (UoS) and the Sharjah Electricity and Water Authority (SEWA), grants number: 19020401122-SEWA and 1902041134-P under the SEWA Chair for Energy \& Water.

\section{Acknowledgments}

The authors would like to thank Hamid Al Naimy, Chancellor of UoS, and Rashid Alleem, Director of SEWA, for facilitating the study.

\section{Reference}

1. A.A. Aly, A.M. Al-Omran, M.M. Alharby, The water quality index and hydrochemical characterization of groundwater resources in Hafar Albatin, Saudi Arabia. Arabian Journal of Geosciences, 8, 6 (2014). 
2. M. Monjerezi, C. Ngongondo, Quality of groundwater resources in Chikhwawa, lower shire Valley, Malawi. Water Quality, Exposure and Health, 4, 1 (2012).

3. C. Singaraja, Relevance of water quality index for groundwater quality evaluation: Thoothukudi District, Tamil Nadu, India. Applied Water Science, 7, 5 (2017).

4. A. Gibrilla, E.K.P. Bam, D. Adomako, S. Ganyaglo, S. Osae, T.T. Akiti, S. Kebede, E. Achoribo, E. Ahialey, G. Ayanu, E.K. Agyeman, Application of water quality index (WQI) and multivariate analysis for groundwater quality assessment of the Birimian and Cape Coast Granitoid Complex: Densu River Basin of Ghana. Water Quality, Exposure and Health, 3, 2 (2011).

5. A.H.A. Abbas, A.S. Dawood, Z.M. Al-Hasan, Evaluation of groundwater quality for drinking purpose in basrahgovernorate by using application of water quality index. Kufa Journal of Engineering, 8, 1 (2017).

6. S. Selvam, G. Manimaran, P. Sivasubramanian, N. Balasubramanian, T. Seshunarayana, GIS-based evaluation of water quality index of groundwater resources around Tuticorin coastal city, South India. Environmental earth sciences, 71, 6 (2013).

7. S. Varol, A. Davraz, Evaluation of the groundwater quality with WQI (Water Quality Index) and multivariate analysis: a case study of the Tefenni plain (Burdur/Turkey). Environmental Earth Sciences, 73, 4 (2015).

8. L.J. Brown, P.N. Dravid, N.A. Hudson, C.B. Taylor, Sustainable groundwater resources, Heretaunga plains, Hawke's bay, New Zealand. Hydrogeology Journal, 7, 5 (1999).

9. A.A. Olajire, F.E. Imeokparia, Water quality assessment of Osun River: studies on inorganic nutrients. Environmental Monitoring and Assessment, 69, 1 (2001).

10. J.M. Ishaku, Assessment of groundwater quality index for Jimeta-Yola area, Northeastern Nigeria. Journal of Geology and Mining Research, 3, 9 (2011).

11. R. Kori, A. Saxena, N. Upadhayay, Groundwater quality assessment of Mandideep industrial area. In National Seminar on Environmental \& Development, Bhopal, 155 (2006).

12. A.A. Mahmood, A.M. Eassa, H.M. Muayad, Y.S. Israa, Assessment of ground water quality at Basrah, Iraq by water quality index (WQI). Journal of University of Babylon, 21, 7 (2013).

13. A.D. Sutadian, N. Muttil, A.G. Yilmaz, B.J.C. Perera, Development of river water quality indices-a review. Environmental monitoring and assessment, 188, 1 (2016).

14. R. K. Horton, An index number system for rating water quality. Journal of Water Pollution Control Federation, 37, 3 (1965).
15. R.M. Brown, N.I. McClelland, R.A. Deininger, R.G. Tozer, A water quality index-do we dare? Water and Sewage Works, 117, 10 (1970).

16. B. Backman, D. Bodiš, P. Lahermo, S. Rapant, T. Tarvainen, Application of a groundwater contamination index in Finland and Slovakia. Environmental Geology, 36 (1998).

17. CCME, Canadian Water Quality Guidelines for the Protection of Aquatic Life: CCME Water Quality Index 1.0, User's Manual. Canadian Council of Ministers of the Environment Winnipeg, (2001).

18. A.K. Shah, G.S. Joshi, Evaluation of water quality index for River Sabarmati, Gujarat, India. Applied Water Science, 7, 3 (2017).

19. C. Sarkar, S.A. Abbasi, QUALIDEX: a virtual instrument for continuous monitoring of water quality indices. Environmental Monitoring and Assessment, 119 (2006).

20. M.A. House, Water quality indices. $\mathrm{PhD}$ thesis, Middlesex Polytechnic, (1986).

21. W. Ocampo-Duque, N. Ferré-Huguet, J.L. Domingo, M. Schuhmacher, Assessing water quality in rivers with fuzzy inference systems: a case study. Environment International, 32, 6 (2006).

22. M.W. Gitau, J. Chen, Z. Ma, Water quality indices as tools for decision making and management. Water Resources Management, 30, 8 (2016).

23. S.M. Liou, S.L. Lo, S.H. Wang, A generalized water quality index for Taiwan. Environmental Monitoring and Assessment, 96 (2004).

24. M. Tomaszkiewicz, M.A. Najm, M. El-Fadel, Development of a groundwater quality index for seawater intrusion in coastal aquifers. Environmental Modelling \& Software, 57 (2014).

25. R.H. Al-Dabbagh, Water Resources Management in Sharjah, UAE. ISESCO Journal of Science and Technology, , 12 (2016).

26. K. Wahlin, A. Grimvall, Roadmap for assessing regional trends in groundwater quality, Environmental Monitoring and Assessment, 165 (2010).

27. A.G. Yilmaz, M.A. Imteaz, S. Gato-Trinidad, I. Hossain, Climate change finger prints in mountainous upper Euphrates Basin, Int Journal Civil Environmental Engineering, 3, 1 (2011).

28. A.G. Yilmaz, B.J.C. Perera, Extreme rainfall nonstationarity investigation and intensityfrequency-duration relationship, Journal of Hydrologic Engineering, 19, 6 (2013).

29. A.G. Yilmaz, I. Hossain, B.J.C. Perera, Effect of climate change and variability on extreme rainfall intensity-frequency-duration relationships: a case study of Melbourne, Hydrology and Earth System Sciences, 18, 10 (2014).

30. A.G. Yilmaz, The effects of climate change on historical and future extreme rainfall in Antalya, Turkey, Hydrological Sciences Journal, 60, 12 (2015). 
31. A.G. Yilmaz, B.J.C. Perera, Spatiotemporal trend analysis of extreme rainfall events in Victoria, Australia, Water Resources Management, 29, 12 (2015).

32. A.A. Masoud, K. Koike, H.A. Mashaly, F. Gergis, Spatio-temporal trends and change factors of groundwater quality in an arid area with peat rich aquifers: Emergence of water environmental problems in Tanta District, Egypt, Journal of Arid Environments, 124 (2016).

33. T.S. Narany, A.Z. Aris, A. Sefie, S. Keesstra, Detecting and predicting the impact of land use changes on groundwater quality, a case study in Northern Kelantan, Malaysia, Science of the Total Environment, 599 (2017).

34. A.G. Yilmaz, A. Shanableh, T. Merabtene, S. Atabay, and N. Kayemah, Rainfall trends and intensityfrequency-duration relationships in Sharjah city, UAE, Int. J. Hydrology Science and Technology, 10, 5 (2020)

35. N. Adimalla, P. Li, S. Venkatayogi, Hydrogeochemical evaluation of groundwater quality for drinking and irrigation purposes and integrated interpretation with water quality index studies. Environmental Processes, 5, 2 (2018).

36. S. Acharya, S.K. Sharma, V. Khandegar, Assessment of groundwater quality by water quality indices for irrigation and drinking in South West Delhi, India. Data in brief, 18 (2018).

37. P. Verma, P.K. Singh, R.R. Sinha, A.K. Tiwari, Assessment of groundwater quality status by using water quality index (WQI) and geographic information system (GIS) approaches: a case study of the Bokaro district, India. Applied Water Science, 10, 1 (2019).

38. A.K. Mohamed, L. Dan, S. Kai, E. Eldaw, S. Abualela, Evaluating the suitability of groundwater for drinking purposes in the North Chengdu Plain, China. In E3S Web of Conferences, EDP Sciences, 81 (2019).

39. S. Khalid, an assessment of groundwater quality for irrigation and drinking purposes around brick kilns in three districts of Balochistan province, Pakistan, through water quality index and multivariate statistical approaches. Journal of Geochemical Exploration, 197 (2019).

40. N. Adimalla, A.K. Taloor, Hydrogeochemical investigation of groundwater quality in the hard rock terrain of South India using Geographic Information System (GIS) and groundwater quality index (GWQI) techniques. Groundwater for Sustainable Development, 10 (2020). 